DOI: $10.15193 /$ zntj/2020/124/348

\author{
WIESŁAW PRZYBYLSKI, BARBARA SIONEK, DANUTA JAWORSKA, \\ ANNA SPYCHALSKA, MARTYNA RUPIŃSKA
}

\title{
WPLYW DODATKU INULINY NA JAKOŚĆ SORBETÓW OWOCOWYCH I WARZYWNYCH
}

\begin{abstract}
Streszczenie
Inulina jest naturalnie występującym prebiotykiem. Jej dodatek do deserów lodowych zwiększa ich walory zdrowotne i nadaje produktom cech żywności funkcjonalnej. Jako substytut tłuszczu inulina obniża wartość energetyczną produktu. Może być czynnikiem teksturotwórczym, poprawiającym konsystencję, smarowność, stabilizującym, zagęszczającym a także może wpływać na smak i zapach produktów. Sorbety są chętnie spożywane, charakteryzują się atrakcyjnymi walorami smakowymi, niską wartością energetyczną, są lekkostrawne i łatwo przyswajalne, dlatego mogą być cennym nośnikiem prebiotyków w diecie. Dodatki prozdrowotne wprowadzane do sorbetów powinny podwyższać jakość sensoryczną produktu albo nie wpływać na nią znacząco. Celem pracy była ocena wpływu inuliny na jakość sensoryczną i wybrane cechy fizykochemiczne sorbetów owocowych i warzywnych. Oceniono jakość sensoryczną i technologiczną sorbetów marchwiowych i truskawkowych w porównaniu z produktami bez dodatku inuliny. Uzyskano sorbety o zadowalającej jakości sensorycznej i dobrych właściwościach fizykochemicznych. Dodatek inuliny (2 i $4 \%$ ) do sorbetów marchwiowych wpłynął istotnie na ich kwasowość i parametry barwy. Zwiększenie udziału inuliny wpłynęło na wzrost jasności barwy i obniżenie intensywności barwy czerwonej i żółtej tych sorbetów. Dodatek inuliny nie wpłynął istotnie na parametry barwy sorbetów truskawkowych. Uzyskane wyniki świadczą o tym, że zawartość inuliny w mrożonych deserach lodowych powinna być ustalana indywidualnie, w zależności od rodzaju sorbetu lodowego. W przypadku sorbetu marchwiowego optymalny jest 2-procentowy jej dodatek, a do sorbetu truskawkowego odpowiedni będzie 4-procentowy dodatek inuliny.
\end{abstract}

Słowa kluczowe: lody, prebiotyk, inulina, jakość sensoryczna

\section{Wprowadzenie}

W ostatnich latach wśród konsumentów obserwowany jest wzrost zainteresowania dietetycznymi, niskotłuszczowymi produktami spożywczymi. Wynika to z upo-

Prof. dr hab. W. Przybylski, dr inż. B. Sionek, dr hab. inż. D. Jaworska, mgr inż. A. Spychalska, inż. M. Rupińska,. Katedra Technologii Gastronomicznej i Higieny Żywności, Instytut Nauk o Żywieniu Człowieka, Szkoła Główna Gospodarstwa Wiejskiego w Warszawie, ul. Nowoursynowska 159 C, 02-776 Warszawa.Kontakt: wieslaw_przybylski@sggw.edu.pl; barbara_sionek@sggw.edu.pl 
wszechniania zdrowego trybu życia. Lody stanowią chętnie spożywany deser. Charakteryzują się atrakcyjnymi walorami smakowymi, są łatwo przyswajalne i lekkostrawne [4]. Tłuszcz zawarty w tradycyjnych lodach jest nośnikiem aromatów, warunkuje ich smak oraz odpowiednią konsystencję i puszystość.

Tradycyjnie lody zawierają $10 \div 16 \%$ thuszczu, który jest składnikiem wysokoenergetycznym, wpływającym na ryzyko wystąpienia chorób układu sercowonaczyniowego. Sorbety to mrożone desery niezawierające tłuszczu oraz składników mleka, cechujące się małą wartością energetyczną w porównaniu z tradycyjnymi lodami. Redukcja lub usunięcie tłuszczu z lodów, korzystne pod względem żywieniowym, może jednak powodować obniżenie jakości sensorycznej lodów [3, 7]. Rozwiązaniem jest wprowadzenie zamiast tłuszczu innych składników o podobnych właściwościach, co pozwala złagodzić niepożądane efekty [9]. Celem stosowania zamienników tłuszczu jest osiągnięcie optymalnej jakości mrożonego produktu, który spełniać będzie oczekiwania konsumentów dotyczące smaku, tekstury i wyglądu. Inulina jest naturalnie występującym węglowodanem roślinnym. Ze względu na zdolności wiązania cząsteczek wody i tworzenia żelu może odgrywać ważną rolę w kształtowaniu tekstury lodów [12]. Stosowanie inuliny nie ogranicza się do jej właściwości jako zamiennika tłuszczu. Jest to prebiotyk, którego dodatek zwiększa walory zdrowotne i nadaje produktowi status żywności funkcjonalnej $[5,11,20]$. Inulina nie jest trawiona w przewodzie pokarmowym człowieka, jej rozkładu dokonują symbiotyczne bakterie jelita grubego. Działanie prozdrowotne inuliny wynika m.in. ze stymulowania rozwoju mikroflory jelitowej człowieka, co wpływa pozytywnie na utrzymanie homeostazy przewodu pokarmowego [8, 19, 21]. Iraporda i wsp. [13] wykazali ponadto, że szczepy symbiotycznych bakterii probiotycznych $L$. paracasei BGP1 i $L$. plantarum CIDCA8327 fermentowały inulinę, co zwiększało ich wzrost i przeżywalność w przewodzie pokarmowym.

Ogueke i wsp. [15] oraz Yasmin i wsp. [23] sugerują, że inulina zmniejsza produkcję toksyn przez bakterie, takie jak Clostridium spp. i Escherichia coli, łagodzi zaburzenia jelitowe, zwiększa biodostępność składników mineralnych, korzystnie wpływa na zaburzenia metaboliczne takie, jak hipercholesterolemia i hiperglikemia. Inulina jest polisacharydem, którego zastosowanie stanowi przykład korzystnych dla zdrowia człowieka interakcji probiotyczno-prebiotycznych.

Celem pracy była ocena wpływu inuliny na jakość sensoryczną i wybrane cechy fizykochemiczne sorbetów owocowych oraz warzywnych.

\section{Material i metody badań}

Materiał do badań stanowiły sorbety truskawkowe i marchwiowe w wariantach: próba kontrolna bez dodatku inuliny oraz próby odpowiednio z: 2- i 4-procentowym dodatkiem inuliny („Zielony listek”, Domos Polska Sp. z o.o.). Do produkcji sorbetów 
marchwiowych używano składników: soku marchwiowego jednodniowego (Victoria Cymes, Polska), wody, cukru białego (Sweet Family, Polska), soku z cytryn zakupionych w lokalnym supermarkecie, bazy do lodów owocowych/warzywnych Gelmix MEC (MEC 3, Włochy). Sorbety marchwiowe wytwarzano z użyciem frezera Technogel model 20-60 Mante (Technogel S.A., Włochy) w lodziarni „Jesz Lody Tradycyjne", Kabaty, Warszawa. W skład sorbetów truskawkowych wchodziły: mrożone truskawki (Hortex, Polska), sok z cytryny i cukier biały. Sorbety truskawkowe wytwarzano z użyciem frezera Extragel 42-60S (Telme, Włochy) w cukierni Olczak i Syn w Piastowie koło Warszawy. Po wyprodukowaniu sorbety były przetrzymywane w zamrażarce szokowej przez ok. $1 \mathrm{~h}$, następnie przewożone do Katedry Technologii Gastronomicznej SGGW w Warszawie i poddawane badaniom.

Kwasowość czynną (pH) sorbetów oznaczano w temp. $20 \pm 2{ }^{\circ} \mathrm{C}$ przy użyciu cyfrowego pH-metru WTW pH 340i (Weilheim, Germany) z kompensacją temperatury, w trzech różnych miejscach próbki. Pomiar parametrów barwy w systemie CIE L*a*b* wykonywano za pomocą spektrofotometru Minolta 3200 (Minolta, Japonia) w 3 powtórzeniach.

Analizę sensoryczną wykonywano metodą skalowania [19], kolejności (szeregowania) [18] oraz Ilościowej Analizy Opisowej QDA [16]. Ocenę metodą skalowania i szeregowania przeprowadzono z udziałem 54 konsumentów, studentów oraz pracowników Katedry Technologii Gastronomicznej i Higieny Żywności SGGW w Warszawie, którzy deklarowali spożywanie lodów i wyrazili dobrowolną zgodę na udział w ocenie. Badanie metodą skalowania obejmowało ocenę 5 wyróżników jakościowych, tj. pożądalności barwy, zapachu, gładkości, rozpływalności i smakowitości. Ocenę sensoryczną metodą QDA - ocenę intensywności wybranych wyróżników jakościowych [16] wykonywał natomiast ośmioosobowy zespół oceniający przeszkolony w zakresie metodyki wykonywanych analiz oraz przebadany pod względem wrażliwości sensorycznej [17]. W dyskusji panelowej wybrano i zdefiniowano 18 wyróżników jakościowych, w tym dwa wyróżniki wyglądu, cztery wyróżniki zapachu, dwa wyróżniki konsystencji: rozpływalność (upłynnianie) w jamie ustnej i odczucie zimna oraz siedem wyróżników smaku. Uwzględniając wzajemne zharmonizowanie powyższych wyróżników, oceniano także jakość ogólną. Intensywność wyróżników oceniano przy użyciu niestrukturowanej, liniowej skali ze sprecyzowanymi określeniami brzegowymi $(0 \div 10$ j.u. - jednostek umownych). Przeprowadzono 2 sesje ocen, zatem każda wartość średnia wynikała z 16 ocen jednostkowych.

Otrzymane wyniki opracowano w programie Statistica PL v. 13. Zastosowano jednoczynnikową analizę wariancji ANOVA, obliczono korelację pomiędzy badanymi wyróżnikami oraz istotność różnic pomiędzy wartościami średnimi metodą najmniejszych istotnych różnic (NIR) przy $\mathrm{p}<0,05$. Dodatkowo pomiędzy jakością ogólną 
a poszczególnymi wyróżnikami obliczono współczynniki korelacji prostej Pearsona. Ich istotność oszacowano przy $\mathrm{p}<0,05$.

\section{Wyniki i dyskusja}

$\mathrm{Na}$ ocenę jakościową lodów duży wpływ ma ich barwa. Rodzaj lodów i nazwa pozostają $\mathrm{w}$ związku z ich barwą i mogą mieć istotny wpływ na decyzję zakupową konsumentów. Jak podają Florowska i Krygier [9], dodatek inuliny powinien nadawać bardziej pożądaną przez konsumentów barwę. Sorbety marchwiowe powinny więc być intensywnie pomarańczowe, aby przypominały barwą świeżo wyciśnięty sok z marchwi. Wyprodukowane sorbety marchwiowe różniły się pod względem barwy w zależności od zawartości inuliny. Lody zawierające 2 i $4 \%$ inuliny charakteryzowały się większą jasnością barwy ( $\left.\mathrm{L}^{*}\right)$ niż sorbety bez dodatku inuliny. Największym nasyceniem barwy czerwonej (a*) charakteryzowały się sorbety bez dodatku inuliny i z 4-procentowym jej udziałem, natomiast najwyższą wartość składowej barwy żółtej (b*) zaobserwowano w sorbetach bez dodatku inuliny (tab. 1). Lum i Albrecht [14] również wykazali wpływ dodatku inuliny na barwę lodów. W lodach z dodatkiem inuliny stwierdzili wzrost wartości składowej barwy a*, przy braku zmian w zakresie parametrów barwy $\mathrm{L}^{*} \mathrm{i} \mathrm{b}^{*}$. W przypadku sorbetów truskawkowych dodatek inuliny nie wpłynął istotnie na zmianę wartości parametrów barwy L*, a*, b* (tab. 2). Podobne rezultaty uzyskali Florowska i wsp. [10] w badaniach nad wpływem dodatku preparatów błonnikowych na wybrane wyróżniki jakości lodów i nie stwierdzili wpływu inuliny na barwę otrzymanych deserów lodowych.

Tabela 1. Wartości parametrów barwy $\mathrm{L}^{*}, \mathrm{a}^{*}, \mathrm{~b}^{*}$ sorbetów marchwiowych z różnymi dodatkami inuliny Table 1. Values of $\mathrm{L}^{*}, \mathrm{a}^{*}, \mathrm{~b}^{*}$ of carrot sorbets with different inulin quantities added

\begin{tabular}{|c|c|c|c||}
\hline \multirow{2}{*}{$\begin{array}{c}\text { Parametry barwy } \\
\text { Colour parameters }\end{array}$} & \multicolumn{3}{|c|}{ Dodatek inuliny / Addition of inulin [\%] } \\
\cline { 2 - 4 } & 0 & 2 & 4 \\
\hline $\mathrm{L}^{*}$ & $58,67^{\mathrm{a}} \pm 0,68$ & $74,14^{\mathrm{b}} \pm 2,29$ & $70,74^{\mathrm{b}} \pm 1,20$ \\
\hline $\mathrm{a}^{*}$ & $29,66^{\mathrm{a}} \pm 2,77$ & $22,41^{\mathrm{b}} \pm 1,09$ & $25,99^{\mathrm{a}} \pm 2,60$ \\
\hline $\mathrm{b}^{*}$ & $39,80^{\mathrm{a}} \pm 4,93$ & $34,44^{\mathrm{b}} \pm 2,86$ & $31,38^{\mathrm{c}} \pm 3,72$ \\
\hline
\end{tabular}

Objaśnienia / Explanatory notes:

W tabeli przedstawiono wartości średnie \pm odchylenia standardowe / Table shows mean values \pm standard deviations; $\mathrm{n}=3$; $\mathrm{a}, \mathrm{b}$ - wartości średnie $\mathrm{w}$ wierszach oznaczone różnymi literami różnią się statystycznie istotnie przy $\mathrm{p} \leq 0,05 /$ mean values in rows denoted by different letters differ statistically significantly at $\mathrm{p}$ $\leq 0.05$.

Wartości pH sorbetów marchwiowych bez inuliny i z 2-procentowym jej dodatkiem były na zbliżonym poziomie (odpowiednio: 4,89 i 4,88). Dodatek $4 \%$ inuliny spowodował natomiast istotne obniżenie pH sorbetów marchwiowych $(4,76)$. Nie wy- 
kazano wpływu dodatku inuliny na $\mathrm{pH}$ badanych wariantów sorbetów truskawkowych - pH tych sorbetów wynosiło $3,03 \div 3,04$.

Tabela 2. Wartości parametrów barwy $\mathrm{L}^{*}, \mathrm{a}^{*}, \mathrm{~b}^{*}$ sorbetów truskawkowych z różnymi dodatkami inuliny Table 2. Values of $L^{*}, a^{*}, b^{*}$ of strawberry sorbets with different inulin quantities added

\begin{tabular}{|c|c|c|c||}
\hline \multirow{2}{*}{$\begin{array}{c}\text { Parametry barwy } \\
\text { Colour parameters }\end{array}$} & 0 & 2 & 4 \\
\cline { 2 - 4 } & $32,25^{\mathrm{a}} \pm 0,79$ & $34,55^{\mathrm{a}} \pm 1,46$ & $33,71^{\mathrm{a}} \pm 1,15$ \\
\hline $\mathrm{L}^{*}$ & $47,83^{\mathrm{a}} \pm 0,28$ & $45,87^{\mathrm{a}} \pm 0,71$ & $47,54^{\mathrm{a}} \pm 1,91$ \\
\hline $\mathrm{a}^{*}$ & $42,50^{\mathrm{a}} \pm 2,24$ & $34,44^{\mathrm{a}} \pm 2,86$ & $40,75^{\mathrm{a}} \pm 6,09$ \\
\hline $\mathrm{b}^{*}$ &
\end{tabular}

Objaśnienia jak pod tab. 1. / Explanatory notes as in Tab. 1.

W ocenie jakości sensorycznej sorbetów marchwiowych metodą skalowania wykazano istotne różnice pomiędzy próbkami pod względem barwy, zapachu, gładkości i rozpływalności (tab. 3). Dodatek inuliny wpłynął na istotne obniżenie intensywności barwy i zapachu oraz zwiększenie intensywności odczuwania wrażenia gładkości i rozpływalności. W badaniach Florowskiej i wsp. [10] stwierdzono, że dodatek preparatów błonnikowych nie miał wpływu na rozpływalność lodów w jamie ustnej i piaszczystość, ale zwiększył ich wodnistość. Należy jednak podkreślić, że w badaniach tych dodatek inuliny wynosił $10 \%$. W badaniach własnych pod względem barwy i zapachu najwyżej oceniona została próbka sorbetów marchwiowych bez dodatku inuliny. Nie wykazano natomiast istotnego wpływu różnej ilości dodawanej inuliny na smakowitość sorbetów. W zdecydowanej większości badanych wyróżników uzyskano noty powyżej 6,8 (tab. 3). Stwierdzono istotne korelacje między barwą a zapachem ( $\mathrm{r}=$ $0,38 ; \mathrm{p} \leq 0,05)$, między gładkością a rozpływalnością $(\mathrm{r}=0,66 ; \mathrm{p} \leq 0,05)$ oraz rozpływalnością a smakowitością $(\mathrm{r}=0,51 ; \mathrm{p} \leq 0,05)$. Pod względem jakości ogólnej w metodzie szeregowania najwyżej oceniona została próbka bez dodatku inuliny, a po niej kolejno próbki z 2- i 4-procentowym jej dodatkiem.

Po zastosowaniu metody QDA wykazano, że dodatek inuliny nie miał istotnego wpływu na jakość ogólną sorbetów marchwiowych (tab. 4). Intensywność not pozostałych wyróżników także nie różniła się istotnie między badanymi wariantami sorbetów, z wyjątkiem barwy pomarańczowej, jasności barwy i smaku marchwiowego. Próby sorbetów z zawartością inuliny na poziomie 2 i $4 \%$ charakteryzowały się wyższą intensywnością jasności barwy i niższą intensywnością barwy pomarańczowej oraz smaku marchwiowego w odniesieniu do próby kontrolnej. Szydłowska i KołożynKrajewska [22] wykazały również, że pomimo zmian barwy, smaku i zapachu sorbety owocowo-herbaciane $z$ dodatkiem inuliny uzyskały akceptację oceniających, chociaż próbki kontrolne charakteryzowały się wyższymi ocenami. 
Tabela 3. Średnie oceny wyróżników jakości sensorycznej sorbetów marchwiowych - metoda skalowania

Table 3. Average ratings of attributes of sensory quality of carrot sorbets as assessed by scaling method

\begin{tabular}{||l|c|c|c||}
\hline \multirow{2}{*}{\multicolumn{1}{|c|}{ Wyróżnik / Attribute }} & \multicolumn{3}{|c||}{ Dodatek inuliny / Addition of inulin [\%] } \\
\cline { 2 - 4 } & 0 & 2 & 4 \\
\hline Barwa / Colour & $7,69^{\mathrm{a}} \pm 1,58$ & $6,62^{\mathrm{b}} \pm 1,63$ & $6,80^{\mathrm{b}} \pm 1,61$ \\
\hline Zapach / Aroma & $6,82^{\mathrm{a}} \pm 1,89$ & $6,03^{\mathrm{b}} \pm 2,00$ & $5,87^{\mathrm{c}} \pm 1,87$ \\
\hline Gładkość / Smoothness & $6,75^{\mathrm{a}} \pm 1,66$ & $7,54^{\mathrm{b}} \pm 1,28$ & $7,62^{\mathrm{b}} \pm 1,45$ \\
\hline Rozpływalność / Deliquescence & $6,99^{\mathrm{a}} \pm 1,66$ & $7,58^{\mathrm{b}} \pm 1,14$ & $7,75^{\mathrm{b}} \pm 1,28$ \\
\hline Smakowitość / Palatability & $6,92^{\mathrm{a}} \pm 1,96$ & $6,85^{\mathrm{a}} \pm 1,60$ & $6,70^{\mathrm{a}} \pm 2,12$ \\
\hline
\end{tabular}

Objaśnienia / Explanatory notes:

$\mathrm{n}=54$. Pozostałe objaśnienia jak pod tab. 1. / Other explanatory notes as in Tab. 1.

Tabela 4. Intensywność badanych wyróżników sorbetów marchwiowych - metoda QDA $[0 \div 10$ j.u.]

Table 4. Intensity of analysed attributes of carrot sorbets - QDA method $[0 \div 10$ c.u.]

\begin{tabular}{||l|c|c|c||}
\hline \multirow{2}{*}{\multicolumn{1}{|c|}{ Wyróżnik / Attribute }} & \multicolumn{3}{c|}{ Dodatek inuliny / Addition of inulin [\%] } \\
\cline { 2 - 4 } & 0 & 2 & 4 \\
\hline Barwa pomarańczowa / Orange colour & $8,62^{\mathrm{a}} \pm 0,90$ & $6,63^{\mathrm{b}} \pm 1,50$ & $6,71^{\mathrm{b}} \pm 1,60$ \\
\hline Jasność barwy / Lightness of colour & $3,58^{\mathrm{a}} \pm 0,90$ & $6,85^{\mathrm{b}} \pm 1,50$ & $6,64^{\mathrm{b}} \pm 1,70$ \\
\hline Zapach marchwiowy / Carrot aroma & $7,62^{\mathrm{a}} \pm 1,50$ & $6,44^{\mathrm{a}} \pm 1,30$ & $6,95^{\mathrm{a}} \pm 1,60$ \\
\hline Zapach słodki / Sweet aroma & $4,90^{\mathrm{a}} \pm 1,60$ & $4,70^{\mathrm{a}} \pm 1,30$ & $4,44^{\mathrm{a}} \pm 1,70$ \\
\hline Zapach kwaśny / Sour aroma & $2,31^{\mathrm{a}} \pm 1,70$ & $1,97^{\mathrm{a}} \pm 1,15$ & $1,77^{\mathrm{a}} \pm 1,50$ \\
\hline Zapach inny / Other aroma & $0,93^{\mathrm{a}} \pm 1,10$ & $1,30^{\mathrm{a}} \pm 1,20$ & $1,30^{\mathrm{a}} \pm 1,20$ \\
\hline Rozpływalność / Deliquescence & $7,71^{\mathrm{a}} \pm 1,10$ & $7,93^{\mathrm{a}} \pm 0,90$ & $7,80^{\mathrm{a}} \pm 1,10$ \\
\hline Odczucie zimna / Feeling of coldness & $6,99^{\mathrm{a}} \pm 1,50$ & $6,67^{\mathrm{a}} \pm 1,60$ & $7,23^{\mathrm{a}} \pm 1,60$ \\
\hline Gładkość / Smoothness & $7,12^{\mathrm{a}} \pm 1,30$ & $7,56^{\mathrm{a}} \pm 1,00$ & $8,12^{\mathrm{a}} \pm 0,90$ \\
\hline Kremowość / Creaminess & $6,93^{\mathrm{a}} \pm 1,60$ & $7,59^{\mathrm{a}} \pm 0,70$ & $7,58^{\mathrm{a}} \pm 1,20$ \\
\hline Smak marchwiowy / Carrot flavour & $8,13^{\mathrm{a}} \pm 1,20$ & $7,34^{\mathrm{b}} \pm 0,90$ & $7,05^{\mathrm{b}} \pm 1,20$ \\
\hline Smak warzywny / Vegetable flavour & $5,64^{\mathrm{a}} \pm 1,50$ & $5,84^{\mathrm{a}} \pm 1,80$ & $4,93^{\mathrm{a}} \pm 1,20$ \\
\hline Smak słodki / Sweet taste & $6,06^{\mathrm{a}} \pm 1,80$ & $6,80^{\mathrm{a}} \pm 1,80$ & $6,86^{\mathrm{a}} \pm 1,90$ \\
\hline Smak kwaśny / Sour taste & $2,77^{\mathrm{a}} \pm 1,70$ & $1,99^{\mathrm{a}} \pm 1,50$ & $1,90^{\mathrm{a}} \pm 1,30$ \\
\hline Smak gorzki / Bitter taste & $2,04^{\mathrm{a}} \pm 1,60$ & $1,21^{\mathrm{a}} \pm 1,30$ & $1,64^{\mathrm{a}} \pm 1,50$ \\
\hline Smak mdły / Insipid taste & $1,93^{\mathrm{a}} \pm 1,40$ & $2,95^{\mathrm{a}} \pm 1,00$ & $2,53^{\mathrm{a}} \pm 1,90$ \\
\hline Smak inny / Other taste & $1,92^{\mathrm{a}} \pm 4,20$ & $1,52^{\mathrm{a}} \pm 1,40$ & $1,17^{\mathrm{a}} \pm 1,11$ \\
\hline Ocena ogólna / Overall quality & $6,76^{\mathrm{a}} \pm 1,75$ & $7,28^{\mathrm{a}} \pm 1,15$ & $7,10^{\mathrm{a}} \pm 1,15$ \\
\hline \hline
\end{tabular}

Objaśnienia / Explanatory notes:

$\mathrm{n}=16$. Pozostałe objaśnienia jak pod tab. 1. / Other explanatory notes as in Tab. 1 .

Na podstawie analizy smakowitości sorbetów truskawkowych metodą skalowania stwierdzono, że 4-procentowy dodatek inuliny wpłynął na istotną poprawę oceny tego 
wyróżnika względem pozostałych wariantów. Noty za wszystkie badane wyróżniki były wysokie i wynosiły powyżej 7 (w skali $0 \div 10$ j.u.), z wyjątkiem smakowitości w wariancie z 2-procentowym dodatkiem inuliny (6,5 j.u.). Pod względem smakowitości wyżej oceniono próbę kontrolną, a najwyżej - próbę z 4-procentowym dodatkiem inuliny (tab. 5).

Tabela 5. Średnie oceny wyróżników jakości sensorycznej sorbetów truskawkowych - metoda skalowania

Table 5. Average ratings of the determinants of sensory quality of strawberry sorbets as assessed by the scaling method

\begin{tabular}{||l|c|c|c||}
\hline \multirow{2}{*}{\multicolumn{1}{|c|}{ Wyróżnik / Attribute }} & \multicolumn{3}{|c||}{ Dodatek inuliny / Addition of inulin [\%] } \\
\cline { 2 - 4 } & 0 & 2 & 4 \\
\hline Barwa / Colour & $8,10^{\mathrm{a}} \pm 1,76$ & $8,29^{\mathrm{a}} \pm 1,06$ & $7,71^{\mathrm{a}} \pm 1,80$ \\
\hline Zapach / Aroma & $7,33^{\mathrm{a}} \pm 1,96$ & $7,21^{\mathrm{a}} \pm 2,18$ & $7,22^{\mathrm{a}} \pm 2,09$ \\
\hline Gładkość / Smoothness & $7,33^{\mathrm{a}} \pm 2,09$ & $7,12^{\mathrm{a}} \pm 2,06$ & $7,78^{\mathrm{a}} \pm 1,48$ \\
\hline Rozpływalność / Deliquescence & $7,56^{\mathrm{a}} \pm 1,70$ & $7,11^{\mathrm{a}} \pm 2,02$ & $7,23^{\mathrm{a}} \pm 2,27$ \\
\hline Smakowitość / Palatability & $7,19^{\mathrm{ab}} \pm 2,45$ & $6,49^{\mathrm{a}} \pm 2,40$ & $7,99^{\mathrm{b}} \pm 1,87$ \\
\hline
\end{tabular}

Objaśnienia / Explanatory notes:

$\mathrm{n}=54$. Pozostałe objaśnienia jak pod tab. 1. / Other explanatory notes as in Tab. 1.

W ocenie metodą szeregowania oceniający za najlepszy uznali produkt z 4-procentowym dodatkiem inuliny, następny był sorbet bez dodatku inuliny i jako trzeci - sorbet z 2-procentowym dodatkiem tego składnika.

Ogólna jakość sensoryczna sorbetów truskawkowych analizowana metodą QDA została oceniona średnio powyżej 6,70 j.u. (tab. 6). Ocena tą metodą potwierdziła najwyższą jakość ogólną sorbetów truskawkowych z 4-procentowym dodatkiem inuliny i brak różnic jakości ogólnej między pozostałymi próbami. Współczynniki korelacji obrazujące wpływ wyróżników na jakość ogólną świadczą, że największy pozytywny wpływ na jakość ogólną miał smak truskawkowy $(\mathrm{r}=0,38, \mathrm{p}<0,05)$ i smak owocowy $(\mathrm{r}=0,32, \mathrm{p}<0,05)$. Badane warianty sorbetów nie różniły się istotnie pod względem ocenianych wyróżników, za wyjątkiem jakości ogólnej i smaku innego (tab. 6). Jak podają Cieślik i Gębusia [6], użycie inuliny do produkcji lodów pozwala otrzymać gładką i jednolitą konsystencję, dzięki czemu zaprojektowane lody charakteryzują się pozytywnymi cechami sensorycznymi i fizycznymi.

Wpływ inuliny na jakość sensoryczną lodów nie został jednoznacznie określony. Akbari i wsp.[1] wykazali, że lody o małej zawartości tłuszczu z dodatkiem inuliny charakteryzowały się dobrą jakością sensoryczną, podczas gdy Akin i wsp. [2] nie zaobserwowali wpływu inuliny na cechy sensoryczne lodów. Z kolei Di Criscio i wsp. [7] zaobserwowali, że lody $\mathrm{z}$ dodatkiem $2,5 \%$ inuliny oceniono najwyżej pod 
Tabela 6. Intensywność badanych wyróżników sorbetów truskawkowych - metoda QDA [0 $\div 10$ j.u.]

Table 6. Intensity of analysed attributes of strawberry sorbets - QDA method $[0 \div 10$ c.u.]

\begin{tabular}{||l|c|c|c||}
\hline \multirow{2}{*}{\multicolumn{1}{|c|}{ Wyróżnik / Attribute }} & \multicolumn{3}{c|}{ Dodatek inuliny / Addition of inulin [\%] } \\
\cline { 2 - 4 } & 0 & 2 & 4 \\
\hline Barwa czerwona / Red colour & $8,36^{\mathrm{a}} \pm 1,30$ & $8,10^{\mathrm{a}} \pm 1,46$ & $8,28^{\mathrm{a}} \pm 1,30$ \\
\hline Jasność barwy / Lightness of colour & $3,14^{\mathrm{a}} \pm 1,82$ & $3,87^{\mathrm{a}} \pm 2,19$ & $3,61^{\mathrm{a}} \pm 2,26$ \\
\hline Zapach truskawkowy / Strawberry aroma & $7,33^{\mathrm{a}} \pm 1,26$ & $7,32^{\mathrm{a}} \pm 1,83$ & $6,84^{\mathrm{a}} \pm 2,24$ \\
\hline Zapach słodki / Sweet aroma & $4,46^{\mathrm{a}} \pm 2,33$ & $2,26^{\mathrm{a}} \pm 3,61$ & $2,33^{\mathrm{a}} \pm 3,30$ \\
\hline Zapach kwaśny / Sour aroma & $3,41^{\mathrm{a}} \pm 2,62$ & $3,61^{\mathrm{a}} \pm 2,30$ & $3,30^{\mathrm{a}} \pm 2,34$ \\
\hline Zapach inny / Other aromar & $0,96^{\mathrm{a}} \pm 1,57$ & $1,18^{\mathrm{a}} \pm 1,66$ & $0,85^{\mathrm{a}} \pm 1,33$ \\
\hline Rozpływalność / Deliquescence & $7,52^{\mathrm{a}} \pm 1,37$ & $12,97^{\mathrm{a}} \pm 22,24$ & $8,10^{\mathrm{a}} \pm 1,04$ \\
\hline Odczucie zimna / Feeling of coldness & $7,19^{\mathrm{a}} \pm 2,08$ & $7,57^{\mathrm{a}} \pm 1,39$ & $7,10^{\mathrm{a}} \pm 1,74$ \\
\hline Gładkość / Smoothness & $6,02^{\mathrm{a}} \pm 2,70$ & $6,40^{\mathrm{a}} \pm 2,32$ & $7,51^{\mathrm{a}} \pm 1,49$ \\
\hline Kremowość / Creaminess & $5,65^{\mathrm{a}} \pm 2,42$ & $6,29^{\mathrm{a}} \pm 2,24$ & $6,95^{\mathrm{a}} \pm 1,89$ \\
\hline Smak truskawkowy / Strawberry flavour & $8,10^{\mathrm{a}} \pm 1,20$ & $7,73^{\mathrm{a}} \pm 1,30$ & $8,33^{\mathrm{a}} \pm 1,29$ \\
\hline Smak owocowy / Fruit flavour & $6,89^{\mathrm{a}} \pm 1,94$ & $6,27^{\mathrm{a}} \pm 1,60$ & $7,11^{\mathrm{a}} \pm 1,60$ \\
\hline Smak słodki / Sweet taste & $5,34^{\mathrm{a}} \pm 2,31$ & $6,18^{\mathrm{a}} \pm 1,70$ & $6,15^{\mathrm{a}} \pm 1,74$ \\
\hline Smak kwaśny / Sour taste & $5,03^{\mathrm{a}} \pm 2,33$ & $3,92^{\mathrm{a}} \pm 2,47$ & $4,82^{\mathrm{a}} \pm 2,87$ \\
\hline Smak gorzki / Bitter taste & $1,02^{\mathrm{a}} \pm 1,20$ & $1,21^{\mathrm{a}} \pm 1,30$ & $1,26^{\mathrm{a}} \pm 1,27$ \\
\hline Smak mdły / Insipid taste & $1,53^{\mathrm{a}} \pm 1,80$ & $2,73^{\mathrm{a}} \pm 2,46$ & $1,75^{\mathrm{a}} \pm 1,84$ \\
\hline Smak inny / Other taste & $1,44^{\mathrm{a}} \pm 1,76$ & $2,79^{\mathrm{a}} \pm 2,80$ & $0,78^{\mathrm{b}} \pm 1,33$ \\
\hline Ocena ogólna / Overall quality & $7,45^{\mathrm{a}} \pm 1,75$ & $6,70^{\mathrm{a}} \pm 1,45$ & $8,15^{\mathrm{b}} \pm 1,15$ \\
\hline
\end{tabular}

Objaśnienia / Explanatory notes:

$\mathrm{n}=16$. Pozostałe objaśnienia jak pod tab. 1. / Other explanatory notes as in Tab. 1.

względem wszystkich badanych cech sensorycznych, natomiast dodatek $10 \%$ inuliny wpłynął na obniżenie oceny akceptacji smaku, konsystencji i jednorodności. Wymienieni autorzy [7] doszli do wniosku, że duży dodatek inuliny (10\%) do lodów niekorzystnie wpływał na właściwości sensoryczne i fizyczne lodów prebiotycznych. Według Szydłowskiej i Kołożyn-Krajewskiej [22] inulina nie wpływała na poprawę barwy, konsystencji i smaku sorbetów owocowo-herbacianych. Na podstawie badań własnych oraz obserwacji cytowanych autorów można zatem tak dobrać dodatek inuliny, aby wpływał na poprawę rozpływalności i konsystencji produktu, przy nieznacznych zmianach smaku i barwy. Konsumenci preferujący żywność funkcjonalną, która może pomóc w stymulowaniu układu odpornościowego lub w zapobieganiu chorobom, oczekują produktów o dobrych walorach smakowych. Lody są dobrym źródłem wartościowych składników, takich jak witaminy czy związki mineralne, stąd są powszechnie i chętnie spożywane niezależnie od wieku. Dodatek inuliny stosowany w produkcji lodów może przyczynić się do wzrostu spożycia prebiotyków. W związku $\mathrm{z}$ tym potrzebne są dalsze badania $\mathrm{w}$ celu określenia optymalnej ilości inuliny, która 
mogłaby zostać dodana do lodów, aby otrzymać funkcjonalny produkt spożywczy o akceptowanych właściwościach sensorycznych.

\section{Wnioski}

1. Dodatek inuliny (2 i $4 \%$ ) do sorbetów marchwiowych wpłynął istotnie na ich kwasowość i parametry barwy. Zwiększenie udziału inuliny wpłynęło na wzrost jasności barwy i obniżenie intensywności barwy czerwonej i żółtej tych sorbetów. Dodatek inuliny nie wpłynął istotnie na parametry barwy sorbetów truskawkowych.

2. Zawartość inuliny w sorbetach lodowych powinna być ustalana indywidualnie, w zależności od rodzaju deseru. Biorąc pod uwagę wyniki oceny sensorycznej, w przypadku sorbetu marchwiowego optymalny okazał się dodatek $2 \%$ inuliny, natomiast w przypadku sorbetowego truskawkowego - 4-procentowy jej dodatek, który wpłynął istotnie na podwyższenie ogólnej oceny sensorycznej i smakowitości lodów w ocenie konsumenckiej.

3. Wyniki przeprowadzonych badań wskazują, że dodatek inuliny do owocowych i warzywnych sorbetów lodowych pozwala na uzyskanie produktów o zadowalającej jakości sensorycznej i dobrych właściwościach fizykochemicznych.

\section{Literatura}

[1] Akbari M., Eskandari M.H., Niakosari M., Bedeltavana A.: The effect of inulin on the physicochemical properties and sensory attributes of low-fat. Int. Dairy J., 2016, 57, 52-55.

[2] Akin M.B., Akin M.S., Kirmaci Z.: Effects of inulin and sugar levels on the viability of yogurt and probiotic bacteria and the physical and sensory characteristics in probiotic ice-cream. Food Chem., 2007, 104, 93-99.

[3] Berger K.G.: Ice cream. In: Food Emulsions. Eds. K. Larson, S. Friberg. Marcel Dekker, New York City 1990, pp. 367-444.

[4] Cais-Sokolińska D., Oziemkowski P., Pikul J.: Wybrane cechy jakościowe lodów jogurtowych na bazie kultur o tradycyjnym składzie i z dodatkiem kultury probiotycznej. Żywność. Technologia. Jakość, 1998, 3 (16), 87-96.

[5] Cieślik E., Gębusia A.: Żywność funkcjonalna z dodatkiem fruktanów. Żywność. Nauka. Technologia. Jakość, 2011, 2 (75), 27-37.

[6] Cieślik E., Prostak A., Pisulewski P.M.: Funkcjonalne właściwości fruktanów. Żywność. Nauka. Technologia. Jakość, 2001, 1 (26), 5-13.

[7] Di Criscio T., Fratianni A., Mignogna R., Cinquanta L., Coppola R., Sorrentino E., Panfili G.: Production of functional probiotic, prebiotic, and synbiotic ice creams. J. Dairy Sci., 2010, 93 (10), 4555-4564.

[8] El-Nagar G., Clowes G., Tudorică C.M., Kuri V., Brennan C.S.: Rheological quality and stability of yog-ice cream with added inulin. Int. J. Dairy Technol., 2002, 55 (2), 89-93.

[9] Florowska A., Krygier K.: Inulina jako zamiennik tłuszczów w produktach spożywczych. Przem. Spoż., 2007, 5, 18-21. 
[10] Florowska A., Wójcik E., Florowski T., Dłużewska E.: Wpływ dodatku preparatów błonnikowych na wybrane wyróżniki jakości lodów. Zesz. Probl. Post. Nauk Roln., 2013, 574, 14-18.

[11] Florowski T., Adamczak L., Fuertes- Hernandez I., Belen Moreno Franco M., Tyburcy A.: Ocena wpływu stopnia substytucji tłuszczu inuliną na wybrane wyróżniki jakości modelowych kiełbas. Nauka. Przyr. Technol., 2010, 4, 1-9.

[12] Franck A.: Technological functionality of inulin and oligofructose. Br. J. Nutr., 2002, 7, 287-291.

[13] Iraporda C., Rubel I.A., Guillermo D., Manrique A.G.A.: Influence of inulin rich carbohydrates from Jerusalem artichoke (Helianthus tuberosus L.) tubers on probiotic properties of Lactobacillus strains. LWT, 2019, 101, 738-746.

[14] Lum A.K., Albrecht J.A.: Sensory evaluation of ice cream made with prebiotic ingredients. RURALS, 2008, 3 (1), 1-9.

[15] Ogueke C.C., Owuamanam C.I., Ihediohanma N.C., Iwouno J.O.: Probiotics and prebiotics: Unfolding prospects for better human health. Pakistan J. Nutr., 2010, 9, 833-843.

[16] PN-EN ISO 13299:2016-05. Analiza sensoryczna. Metodyka. Ogólne wytyczne ustalania profilu sensorycznego.

[17] PN-EN ISO 8586:2014-03. Analiza sensoryczna. Ogólne wytyczne wyboru, szkolenia i monitorowania wybranych oceniających i ekspertów oceny sensorycznej.

[18] ISO 8587:2006. Sensory analysis. Methodology. Ranking.

[19] PN-ISO 4121:1998. Analiza sensoryczna. Metodologia. Ocena produktów żywnościowych przy użyciu metod skalowania.

[20] Ramirez-Farias C., Slezak K., Fuller Z., Duncan A., Holtrop G., Louis P.: Effect of inulin on the human gut microbiota: Stimulation of Bifidobacterium adolescentis and Faecalibacterium prausnitzii. Br. J. Nutr., 101, 541-550.

[21] Roberfroid M.: Prebiotics: The concept revisited. J. Nutr., 2007, 137, 830-837.

[22] Szydłowska A., Kołożyn-Krajewska D.: Wpływ dodatku oligofruktozy na wybrane wyróżniki jakości probiotycznych sorbetów owocowo-herbacianych. Żywność. Nauka. Technologia. Jakość, 2016, 5 (108), 82-94.

[23] Yasmin A., But M.S., Afzaal M., van Baak M., Nadeem M.T., Shahid M.Z.: Prebiotics, gut microbiota and metabolic risks: Unveiling the relationship. J. Funct. Foods, 2015, 17, 189-201.

\section{EFFECT OF INULIN ADDITION ON QUALITY OF FRUIT AND VEGETABLE SORBETS}

\section{S u m m a ry}

Inulin is a naturally occurring prebiotic. Adding inulin to ice desserts enhances their health qualities and gives products characteristics of functional food. As a fat substitute inulin decreases the food energy of a product. It can be a texture modifier used to improve consistency and spreadability, a stabiliser and a thickener; also it can affect the taste and aroma of products. Sorbets are willingly consumed; they are characterised by a distinctive taste and low food energy; they are light and easily digestible; thus they can be a valuable carrier of probiotics in the diet. When added to sorbets, the health-promoting additives should increase the sensory quality of the product or not significantly affect it. The objective of the research study was to assess the effect of inulin on the sensory quality and selected physical-chemical parameters of fruit and vegetable sorbets. There was assessed the sensory and technological quality of carrot and strawberry sorbets in comparison with the products without the addition of inulin. The manufactured sorbets showed an acceptable sensory quality and good physical-chemical properties. The addition of inulin ( 2 and $4 \%$ ) to carrot sorbets significantly impacted their acidity and colour parameters. The increase in the proportion of inulin caused the colour of the sorbets to become lighter and their red 
and yellow colours to become less intense. Inulin added to strawberry sorbets did not significantly affect their colour parameters. The results obtained prove that the content of inulin in frozen desserts should be individually determined depending on the kind of sorbet. In the case of carrot sorbet optimal is $2 \%$ of inulin; as for strawberry sorbets recommended for adding is $4 \%$ of inulin.

Key words: ice cream, prebiotic, inulin, sensory quality 